\title{
An Empirical Assessment of the operational efficiency of electronic banking: Evidnce of Nigerian banks
}

\author{
*Ekwueme, C. M, Ph.D, *Egbunike, P. A, Ph.D \\ \& **Amara Okoye, Msc \\ *Nnamdi azikiwe university, awka \\ **University of Nigeria, Nsukka.
}

\begin{abstract}
:
This study assessed the operational efficiency of electronic banking in Nigeria with a focus on the twenty-one Commercial banks listed on the Nigerian stock exchange at the end of year 2010. It examined the practice of e-banking since its inception in Nigeria in order to determine the significance of its relationship with improvement in core banking operations. Secondary data were used for this study. Correlation technique as well as simple percentage were used to analyzed the data, and the student's t-distribution was used to test the hypotheses. The study revealed that the practice of e-banking in Nigeria is significantly related to increased operational efficiency of Nigerian banks, though the security problem was found to exist. Based on these findings, the researchers recommend among others that government through CBN should provide adequate security measures towards the various e-banking products in Nigeria.
\end{abstract}

Introduction: $21^{\text {st }}$ century has witnessed tremendous technology advancement in all spheres of human endeavour. The increasing advancement in information and communication technology has transformed the landscape of any business in the present world while this change is not unique to banking, banking industry now operates in a complex and competitive environment characterized by these changing conditions and highly unpredictable economic climate. Information and communication Technology (ICT) is at the centre of this global change curve. In Nigeria, Modern banks now realize that only those that overhaul their payment service delivery and operations are likely to survive and prosper in the $21^{\text {st }}$ century. This is due to pressure of globalization and rapidly changing technology (Connel and Saleh, 2004). 
Business today is conducted in an age of highly complex technology imposing on banking officials the need to implement sophisticated banking systems which accord with present day needs. Consequently paper based transactions are now being replaced by electronic based transactions (Agboola, 2006).

In recent years in Nigeria, there has been persistent public outcry as regards the new challenges, the electronic banking since its inception in 1996 has brought to financial institutions (banks) and general public. To many people, banking transaction via the internet are insecure and often congested. Hence, interruption is usually experienced in banking operations due to network failures. This hindered customers from carrying out transactions at that point in time. Besides, many people do not know what e-banking entails, or how to use its products. This aids in revealing the secrete PIN number (in the case of ATM card and other cards transaction) to the third party by the illiterate cardholders (customers) at any time they want to make withdrawals as they always request for assistance. Consequently there are increases in fraudulent activities in the banking industry. The CBN Annual Report and Statement of Accounts, (2009) have it that, the number of reported cases of attempted or successful fraud and/or forgery in the banking industry rose in 2009. According to the report, seventy percent of the fraud cases were perpetrated via the electronic system. These issues to this group of people have posed problems to the smooth operations of electronic banking in Nigeria. Worried by this ever increasing spate of fraud and forgeries in the banking sector, the researchers raised a number of research questions thus:

1. What is the extent of correlation between e-banking practices in Nigeria and increased insecurity of banking transactions?

2. What is the degree of relationship between e-banking practices in Nigeria and total credit facilities granted by Nigerian banks?

3. To what extent has e-banking improved the level of deposits (savings and time deposits) with Nigerian banks?

It is therefore intended that the following hypothesis will guide the test of the above research questions: 
1) There is no significant relationship between e-banking practices in Nigeria and the rate of increase in the insecurity of banking transactions.

2) The practice of e-banking in Nigeria is not significantly related to increased total credit facilities granted by Nigerian banks.

3) Significant relationship does not exist between the level of deposits (savings and time deposits) with Nigerian banks and e-banking practices in Nigeria.

The remainder of this paper is organized in the following manner, section 2 provides the Review of the Literature under investigation. Section 3 presents the methodology. The results of the empirical findings follow in section 4 . Finally, conclusions and recommendations are presented in section 5 .

\section{Review of related Literature}

\section{Evolution of E-banking in Nigeria}

Banking has come a long way from the time of ledger cards and other manual filling system to the computer age. Computerization in the Nigerian banking industry was introduced first in the 1970s by Society General Bank (Nigeria) Limited. Until the mid 1990, few banks that were computerized adopted the Local Area Network (LAN) within the bank branches. The sophisticated ones among the banks then implemented the WAN by linking branches within cities while one or two implemented intercity connectivity using leased lines (Salawu and Salawu, 2007).

Later on, the Scenario became different, banks have not only adopted computerization but advanced from very simple and basic retail operations of deposits and cash withdrawal as well as cheque processing, to the delivery of sophisticated products which came as a result of keen competition in view of unprecedental upsurge in the number of banks and branches as well as advancement in the information technology. There was the need to innovate and modernize banking operation in the face of increased market pressure and customers demand for improved service delivery and increased 
convenience. The adoption of internet and electronic banking therefore become an imperative (Salawu and Salawu, 2007).

According to Sanusi (2002) as cited by Dogarawa (2005). The introduction of e-banking (e-payment) products in Nigeria commenced in 1996 when the CBN granted All States Trust Bank approval to introduce a closed system electronic purse called ESCA. This was followed in February 1997, with the introduction of a similar product called "Paycard", by Diamond Bank. The card based e-money products assumed an open platform with the authorization in February 1998, of Smartcard Nigeria PLC, a company floated by a consortium of 19 banks to produce and mange cards called value card and issued by the member banks. Another consortium of more than 20 banks under the auspices of Gemcard Nigeria Limited obtained CBN approval in November 1999 to introduce the "Smartpay" Scheme (Dogarawa, 2005). The number of participating banks in each of the two schemes had been rising since then.

Furthermore, the CBN additionally granted approval to a number of banks to introduce international money transfer products, telephone banking and on-line banking via the internet, though on a limited scale (Dogarawa 2005, cite Abdulhakeem, 2002). Mention must also be made on the deployment of Automated Teller Machine (ATM) by some banks to facilitate cards usage and further enhance their service delivery. Today, virtually all Banks in Nigeria now have a website. The service or ordering bank drafts or certified cheque made payable to third parties has also been increasingly automated (Irechukwu, 2000).

\section{Major Product of Electronic Banking in Nigeria}

Smart card or electronic pulse (use of point of sale terminal), Electronic Fund Transfer (ETF), Internet banking, Automated Teller Machine (ATM), Telephone banking and personal computer banking are the major products of electronic banking in Nigeria.

Smart Card: This is a card issued to a customer (a person who has a current account with the bank) by a member bank of SMART CARD Nigeria Limited to aid them in their transactions. Ideally, each card 
holder (customer, to whom a card or electronic pulse is issued) should be an existing customer with a member bank of the consortium responsible for such e-money product. The card issued to the customer is usually PIN protected (Personal Identification Number), and each card holders has access/pass code or password different from any other person's. Such a pass code must be kept secret and must be changed any time it becomes known to someone else.

The bank is exempted from any form of liability whatsoever for complying with any or all instrument(s) given by means of the customer's pass code or access code if by any means any of such code becomes known to a third party. At intervals, the card should be taken to any branch or designated branch as the case may be to UPLOAD (Similar to crediting the account). When this is done, it reduces the cash value of the current account with the bank and increases the cash value of the card. Uploading is done using a Bank Teller Terminal (BTT).

The merchants are designated centres where cardholders can transact business using electronic pulses or card. They include such places as restaurants, hotels, airlines, supermarkets and lately some pharmaceuticals. Such merchants are normally equipped with point of sales terminal (POS), a device mounted by each merchant for use by cardholders. To settle their transaction, cardholders insert their cards into the POS to store the transaction, issue receipt and disclose the balance on the card. As a matter of policy, merchants normally targeted for the scheme are outlets with a business turnover of not less than one million naira annually. Merchants, unlike card holders, need not have an account with the bank. But as a matter of necessity, they are required to open an account with the bank.

Member banks of the consortium intermediate between cardholders, merchants, and issuers of the e-money value. The banks help to reconcile the card balances with the current account of the cardholder domiciled in the bank. Banks normally charge interest for the role though this varies from bank to bank. Like merchants, the banks also have point of sales terminal to satisfy customers who need cash for other non business related transactions. (Iyabi, 1997). Other card 
transactions include the use of debit card, credit card, master card, visa card etc. these cards have similar function with the smart card discussed above.

Electronic Fund Transfer (EFT): This is an electronic oriented payment mechanism. It allows customers accounts to be credited electronically within 24 hours (Ugwu, et al, 1999). Mark (1975) classified the basic elements of ETF system into three: Clearing network characteristics, remote service or points of sales characteristics and pre authorized debit and/or credit characteristics.

a. Clearing network characteristics: This deals with automated clearing service and this manifest in the use of Magnetic Ink Character Reader (MICR) in Nigeria.

b. The remote service or point of sale characteristics address the units of banking activities that transfer funds from one bank current or savings accounts to another bank current or savings account. The transfer is always authorized and the record is kept on file of that authorization. There is also a secondgeneration remote service unit that is capable of electronically placing a third party into the customer-financial institution communication link. This is known as POS (Point Of Sale Terminals). POS terminals handle cheque verification, credit authorization, cash deposit and withdrawal, and cash payment. This enhances electronic fund transfer at the point of sale (EFT POS). EFTPOS enables a customer's account to be debited immediately with the cost of purchase in an outlet such as a supermarket or petrol station (Ugwu, et al, 1999). The purchase price is debited on the buyer's account and credited on the seller's account.

c. Pre-authorized debit and/or credit characteristics of the EFT manifest in the use of cards. Plastics cards are used to identify customers and pass same to machine to initiate a paper or electronic payment. Electronic cards are microchips that store electronic card, which is only cheque guaranteed (Ugwu, et al 1999). Financial institutions issue credit cards in order to provide credit facilities to their customer and debit cards to ease payment. Credit cards are used as means of borrowing or as a 
convenient method of payment. Debit card is a charge card designed as a convenient method of payment in place of cash or cheque.

Electronic fund transfer has been variously designed to ease international transfer of money. In 1977, the international payment system known as SWIFT (Society for Worldwide Inter-bank Financial Telecommunication) became operational. SWIFT enables user banks to use electronic mode to transfer international payments, statements and other banking messages. In Nigeria, First Bank Western Union, Monogram of United Bank for Africa among others perform international Funds transfer. Due to regulatory policy, monies can only be received and not sent from Nigeria.

It is pertinent to mention that connectivity via the use of Local Area network

(LAN) and Wide Area Network (WAN) has facilities electronic transfer of

funds.

Mobile Telephone banking: Mobile phones are increasingly being used for financial services in Nigeria. Banks are enabling the customers to conduct some banking services such as account inquiry and funds transfer through the mobile telephone. Alert $\mathrm{Z}$ of Zenith bank is an example of e-banking services via mobile phone (SMS). This notifies the customer of any transaction on his/her account.

Personal Computer (PC) Banking: PC banking refers to use of computer hardware, software and telecommunications to enables retail customers' access to both specific account and general information on bank's products and services through a personal computer.

Automated Teller Machine: This is an electronics device which allows a bank's customers to make cash withdrawals and check their account balances at any time without the need for a human teller. Many ATMs also allow people to deposit cash or cheques, transfer money between their bank accounts or even buy postage stamps. To withdraw cash, make deposits, or transfer funds between accounts, you generally 
insert an ATM card and enter your personal identification number (PIN). Some ATMs impose a surcharge, or usage fee, on consumer who are not member of their institution or on transactions at remote locations. ATMs must disclose the existence of a surcharge on the terminal screen or on a sign next to the screen. Check the rules of your institution to find out when or whether a surcharge is imposed.

If one incurred a loss or stolen ATM card, he/she should notify the issuer by certified letter, return receipt requested, so you can prove that the institution received your letter. Keep a copy of the letter you send for your records. If you fail to notify the institution of the error within 60 days, you may have little recourse. Under Federal Law, the institution has no obligation to conduct an investigation if you have missed the 60 -days deadline. After notification about an error on your statement, the institution has 10 business days to investigate. The financial institution must tell you the results of it's investigation within three business days after completing it and must correct the error within one business day after determining that the error has occurred. If the institution needs more time, it may take up to 45 days to complete the investigation but only if the money in dispute is returned to your account and you are notified promptly of the credit. At the end of the investigation, if no error has been found, the institution may take the money back if it sends you a written explanation.

Recently in Nigeria, the CBN issued a warning that banks will be liable for ATM frauds committed with cards issued without card owners requesting for it. Also, the apex bank advised all banks to commence the issuance of ATM verve cards (which is more secured) in place of ATM magnetic strip cards.

The Internet banking: Internet is a global network of computers. It is a collection of computers networks, computers and millions of users, who share a compatible means for interacting with one another to exchange information. (Awe, 1998). The word "internet" is the abbreviation for international network for communication. It has the following services: 
a. $\quad$ Electronic mail (E-mail): Awe (1998) described the E-mail as the letter to anyone, anywhere in the world but doing it electronically.

b. E-mail to fax: According to Olurunta (1997), this is a supplementary service to the e-mail services. It is designed to enable a subscriber send messages to those who have no e-mail facility but fax facilities.

c. World Wide Web: This is the services in which anyone with information or goods to sell, advertise or gives away could place the information in a place called a 'website'. Those in need for such information will then use special software called the "Browser" to link up with websites and read or download any information they want.

d. Chart: this is a system that permits time type conversations among internet users.

e. Telnet: According to Awe (1998), this is a basic internet services which allows one to physically access remote computers as if they were local to him. To use Telnet, you must have the Internet address of the network computer and a valid user name and a password that logs you into the remote computer as if it were local machines.

f. File Transfer Protocol (FTP): It is the standard protocol for carrying files from computer to computer on the internet. Similar to Telnet, FIP allows you access to remote machines. The internet enables electronic banking through connections to the bank for a wide variety of services.

The use of the various forms of e-banking products grew significantly in the year 2009 as the volume and value of the transactions stood at N114.6 million and N645.04 billion respective (CBN annual report and statement of account, 2009). Hence, table 2.5.7 shows the increase in utilization of e-banking product among Nigerians in 2009 as against 2008. 
Table 1: Market share in the e-payment market in 2008 and 2009

\begin{tabular}{|l|l|l|l|l|}
\hline E-payment segment & $\begin{array}{l}\text { Volume } \\
\text { (millions) }\end{array}$ & $\begin{array}{l}\text { Value (N' } \\
\text { Billion) }\end{array}$ & \multicolumn{2}{|l|}{} \\
\hline & 2008 & 2009 & 2008 & 2009 \\
\hline ATM transactions & 60.1 & 109.2 & 399.71 & 548.60 \\
\hline $\begin{array}{l}\text { Web (Internet } \\
\text { payment) }\end{array}$ & 1.6 & 2.7 & 25.05 & 84.15 \\
\hline $\begin{array}{l}\text { Online POS } \\
\text { transaction }\end{array}$ & 1.2 & 0.9 & 16.12 & 11.04 \\
\hline $\begin{array}{l}\text { Mobile telephone } \\
\text { payment }\end{array}$ & 3.2 & 1.8 & 0.70 & 1.26 \\
\hline Total & 66.1 & 114.6 & 441.6 & 645.05 \\
\hline
\end{tabular}

Source: Extracted from CBN Annual Report and Statement of Account for the year ended $31^{\text {st }}$ December, 2009.

\section{E-banking and Operational Efficiency of Nigerian Banks}

Operational efficiency of e-banking in Nigeria can be assessed by critically evaluating the banking operations between two periods. These include pre and post e-banking period in Nigeria.

\section{Pre-Electronic banking period (1982-1995)}

The first bank in Nigeria was established in 1892 (then African Banking Corporation). There was no banking legislation until 1952 when three foreign banks (Bank of British West Africa, Barclays Bank, and British and French Bank) and two indigenous banks (National Bank of Nigeria and African Continental Bank) were established, with a total number of 40 branches (Osabuohien, 2008 cite Iganiga, 1998). As at 1988, the Nigerian banking system consisted of the CBN, 42 commercial banks and 24 Merchant Bank (Osabuohien, 2008 cite Iganiga, 1998 and Adam, 2005). Between the period of 1892-1995, banking transactions were mostly paper-based transactions. Manual processing of documents were in use. These resulted to slow pace of banking operations vis-à-vis their employees' productivity cum general performance. Ovia (2005) have it that banks' customers were inevitably made to spend several hours in the congested banking halls in carrying out their transactions. This implies that pre-electronic banking periods were days when 
banking halls are characterized by long queues manly as a result of delays in the traditional banking operations thereby leading to low operational efficiency in the banking sector.

\section{Post E-banking Period (1996-present)}

The introduction of e-banking (e-payment) products in Nigeria commenced in 1996 (Dogarawa, 2005 cite Sanusi, 2002). It is a situation whereby Nigerian banks perform their banking operations through electronic means. Irechukwu (2000) lists some banking services that have been revolutionized through the use of ICT as including account opening, customer account mandate, and transaction processing and recording. Akinlili (1996) added that ICT application can be seen in almost all areas of banks' activities. This phenomenon is capable of bringing about speedy operations and enhanced productivity (Osabuohien, 2008 cite Adeoti, 2005; Ova, 2005). Electronic banking became prominent after the Central Bank of Nigeria banking reformation exercise in June 2004, which was geared towards reducing the number of banks in the country and making the emerging banks much stronger and reliable. The surviving banks after the reformation exercise have been able to catch up with global developments and now operate with better service delivery.

Before this period, it took time for transaction to be completed on the floor of Nigerian banks, customers were driven away from banking transactions just because of poor services and facilities. But with ebanking, the Scenario is different. The banks official website (all the commercial banks have their own websites) properly enlightened customer or public as to the activities of the banks. It can give any visitor to customer all the information about the operations of the banks such as account opening information, information about internet banking viz: access to online balance of customer's account, transfer of funds to third party and access to all transfer history on customers account. Customers do not need to wonder whether a cheque has cleared or a deposit has been posted. At the click of a button, customers can easily check the status of their current, saving and any other type of account. Also. Customers do not have to wait till month end for historical, snail mail statements of account, through online banking, 
banks can provide immediate account enquires/ statements online for customers. Furthermore, e-banking gives the ability to pay bills electronically. Since banks tie-up with various companies, services providers and insurance companies across the country, a customer can facilitate payment of electricity and telephone bills, online registration, scratch card of universities and insurance premium bills. Customers can also transfer any amount from one account to another of the same bank or another bank. Geographical locations are no longer barriers to financial transactions.

Conclusively, the application of Information Technology (IT) in Nigerian banks has enabled banks to achieve a higher level of efficiency (decongestion in the banking hall), provide cost effective services and offer a wide spread flow of information at no time and at a reasonable cost. Therefore only banks that overhaul the whole of their payment and delivery systems and apply ICT to their operations are likely to survive and prosper in the new millennium (Woherem, 2000).

\section{Central Bank of Nigeria Guidelines on Electronic Banking in Nigeria.}

The CBN recognizes that electronic banking and payments services are still at the early stages of development in Nigeria. Arising from the three major roles of the $\mathrm{CBN}$ in the areas of monetary policy, financial system stability and payments system oversight, the CBN Technical Committee on E-banking has produced a report, which anticipates the likely impact of the movement towards electronic banking and payments on the achievement of CBN's core objectives. Following from the findings and recommendations of the Committee, four categories of guidelines have been developed as follows:

a. Information and Communications technology (ICT) standards, to address issues relating to technology solutions deployed, and ensure that they meet the needs of consumers, the economy and international best practice in the areas of communication, hardware, software and security.

b. Monetary policy, to address issues relating to how increased usage of internet banking and electronic payments delivery 
channels would affect the achievement of CBN's monetary policy objectives.

c. Legal guidelines to address issues on baking regulations and consumers rights protection.

d. Regulatory and Supervisory, to address issues that, though peculiar to payments system in general, may be amplified by the use of electronic media.

The Guidelines are expected to inform the future conduct of financial Institutions in e-banking and electronic payments delivery. A detailed report of the Technical Committee on e-banking, which resulted in these guidelines, is available below (CBN, 2003).

\section{The Guidelines}

\section{i. Technology and Security Standards}

CBN will monitor the technology acquisitions of banks, and all investment in technology, which exceeds $10 \%$ of free funds, will hence forth be subject to approval. Where banks used third parties or outsource technology, banks are required to comply with the CBN guidelines.

\section{ii. Standards for Computer network and Internet}

a. Network used for transmission of financial data must be demonstrated to meet the requirements specified for data confidentiality and integrity.

b. Banks are required to deploy a proxy type firewall to prevent a direct connection between the banks back end systems and the internet.

c. Banks are required to ensure that the implementation of the firewalls addresses the security concerns for which they are deployed.

d. For dial up services, banks must ensure that the moderns do not circumvent the firewalls to prevent direct connection to the bank's back end system.

e. External devices such as Automated Teller Machines (ATMs), personal Computer, (PC's) at remote branches, kiosks, etc. permanently connected to the bank's network and passing 
through the firewall must at the minimum address issues relating to non-repudiation, data integrity and confidentiality. Banks may consider authentication to other methods.

f. Banks are required to implement proper physical access controls over all network infrastructures both internal and external.

\section{iii. Standard on protocols}

Banks must take additional steps to ensure that whilst the web ensure global access to data enabling real time connectivity to the bank's back-end systems, adequate measures must be in place to identify and authenticate authorized user while limiting access to data as denied by the Access Control List.

\section{iv. Standards on Application and System software}

a. Electronic banking application must support centralized (bankwide) operations of branch level automation. It may have a distributed, client server or three tier architects based on a file system or a Database Management System (DBMs) package. Moreover, the product may run on computer systems of various types ranging from PC's open systems, to proprietary main frames.

b. Banks must be mindful of the Limitations of communications for server/ client-based architecture in an environment where multiple servers may be more appropriate.

c. Banks must ensure that their banking applications interface with a number of external sources. Banks must ensure that applications deployed can support these external sources (Interface Specification or other CBN provided interfaces) or provide the option to incorporate these interfaces at a later date.

d. A schedule of minimum data interchange specifications will be provided by the CBN.

e. Banks must ensure continued support for their banking application in the event the supplier goes out of business or is unable to provide service. Banks should ensure that at a minimum, the purchase agreement makes provision of this possibility. 
f. The bank's information system (IS) infrastructure must be properly and physically secured. Banks are required to develop policies setting out minimum standards of physical security.

g. Banks are required to identify an ICT compliance officer whose responsibilities should include compliance with standard contained in these guidelines as well as the bank's policies on ICT.

h. Banks should segregate the responsibilities of the information Technology (IT) security Officer/ group which deals with information systems security from the IT division, which implements the computer systems.

\section{v. Standards on Delivery Channels}

Mobile Telephony: mobile phones are increasingly being used for financial services in Nigeria. Banks are enabling the customers to conduct some banking services such as account inquiry and funds transfer. Therefore the following guidelines apply:

a. Networks used for transmission of financial data must be demonstrated to meet the requirements specified for data confidentially, integrity and non repudiation.

b. An audit trial of individual transactions must be kept.

Automated Teller Machine (ATM): In addition to guidelines on ebanking in general, the following specific guidelines apply to ATMs"

a. Networks used for transmission of ATM transactions must be demonstrated to meet the guidelines specified for data confidentiality and integrity.

b. In view of the demonstrated weaknesses in the magnetic stripe technology, banks should adopt the chip (smart card) technology as the standard, within 5 years. For banks that have not deployed ATMs, the expectation is that chip based ATMs would be deployed. However, in view of the fact that most countries are still in the magnetic stripe conversion process, banks may deploy hybrid (both chip and magnetic stripe) card readers to enable the international cards that are still primarily magnetic stripe to be used on the ATMs. 
c. Banks will be considered liable for fraud arising from card skimming and counterfeiting except where it is proven that the merchant is negligent. However, the cardholder will be liable for frauds arising from PIN misuse.

d. Banks are encountered to join shared ATM networks.

e. Banks are required to display clearly on the ATM machines, the Acceptance Mark of the cards usable on the machine.

f. All ATMs not located within bank premises must be located in a manner to assure the safety of the customer using the ATM. Appropriate lighting must be available at all times and a mirror may be placed around the ATM to enable the individual using the ATM to determine the locations of persons in their immediate vicinity.

g. ATMs must be situated in such a manner that passers by cannot see the key entry of the individual at the ATM directly or using the security devices.

h. ATMs may not be placed outside buildings unless such ATM is bolted to the floor and surrounded by structures to prevent removal.

i. Additional precaution must be taken to ensure that any network connectivity from the ATM to the bank or switch are protected to prevent the connection of other devices to the network point.

j. Non-bank institutions may own ATMs, however such institutions must enter into an agreement with a bank for the processing of all the transactions at the ATM. If an ATM is owned by a non-bank institution, processing banks must ensure that the card readers, as well as other devices that captures/ store information on the ATM do not expose information such as the PIN number or other information that is classified as confidential. The funding (cash in the ATM) and operation of the ATM should be the sole responsibility of the bank.

k. Where the owner of the ATM is a financial institution, such owner of the ATM must also ensure that the card reader as well as other devices that capture information on the ATM does not expose/ store information such as the PIN number or other information that is classified as confidential to the owner of the ATM. 
1. ATMs at bank branches should be situated in such a manner as to permit access at reasonable times. Access to these ATMs should be controlled and secured so that customers can safely use them within the hours of operations. Deployers are to take adequate security steps according to each situation subject to adequate observance of standard security policies.

m. Banks are encountered to install cameras at ATM locations. However, such cameras should not be able to record the keystrokes of such customers.

n. At the minimum, a telephone line should be dedicated for fault reporting, and such a number shall be made known to users to report any incident at the ATM. Such facility must be manned at all times the ATM is operational.

\section{Internet Banking}

Banks should put in place procedures for maintaining the bank's web site which should ensure the following:

a. Only authorized staff should be allowed to update or change information on the web site.

b. Updates of critical information should be subject to dual verification (e.g. interest rates)

c. Web site information and links to other web sites should be verified for accuracy and functionality.

d. Management should implement procedures to verify the accuracy and content of any financial planning software, calculators, and other interactive programme available to customers on an Internet Web site or other electronic banking services.

e. Links to external web sites should include a disclaimer that the customer is leaving the bank's site and provide appropriate disclosures, such as noting the extent, if any, of the bank's liability for transactions or information provided at other sites.

f. Banks must ensure that the Internet Service Provider (ISP) has implemented a firewall to protect the bank's web site where outsourced.

g. Banks should ensure that installed firewalls are properly configured and institute procedures for continued monitoring and maintenance arrangements are in place. 
h. Banks should ensure that summary-level reports showing website usage, transaction volume, system problem logs, and transaction exception reports are made available to the bank by the web administrator.

\section{Methodology}

Documentary data collection was used. Data including the volume of ebanking products utilized in Nigeria for years 2005 - 2010, fraud and forgery in banking industry between years 2005 and 2010, savings and time deposit with Nigerian commercial Banks for years 2005 - 2010 and total credit facilities granted by Nigerian Commercial Banks between 2005 and 2010 were extracted from CBN Annual Report and Statement of Account (2007, 2009 and 2010).

Data gathered were presented in tables and analyzed using simple percentage and corelational technique (Pearsonian product moment correlation coefficient). Students' t-significance test was used in testing the hypotheses. This was as a result of small sample size used. Hence, the formula for Pearson's correlation coefficient is

While the formula for t-test statistics (when testing the significance of correlation coefficient) is

$$
t=\frac{r \sqrt{n-2}}{\sqrt{1-r^{2}}}
$$

Where:

$$
\begin{array}{lll}
\mathrm{t} & = & \mathrm{t}-\text { statistics } \\
\mathrm{n} & = & \text { number of observations or cases } \\
\mathrm{r} & = & \text { correlation coefficient } \\
\mathrm{n}-2 & = & \text { degree of freedom }
\end{array}
$$

Also, simple percentage formula is shown below:

$$
\frac{\text { Volume of each } \mathrm{e} \text {-banking product used }}{\text { Total volume of all } \mathrm{e} \text { - banking product used }} \times \frac{100}{1}
$$




\subsection{Result Discussions}

Test of Hypothesis 1

There is no significant relationship between e-banking practices in Nigeria and the rate of increase in the insecurity of banking transactions.

Table 2: The extent of correlation between e-banking practices in Nigeria and increased insecurity of Nigerian banking transactions.

\begin{tabular}{|l|l|l|l|l|l|}
\hline Period & $\begin{array}{l}\text { Volume of e- } \\
\text { banking } \\
\text { products } \\
\text { utilized in } \\
\text { Nigeria } \\
\text { (million) } \\
\text { (X) }\end{array}$ & $\begin{array}{l}\text { No. of cases of } \\
\text { Fraud and } \\
\text { Forgery in } \\
\text { banking } \\
\text { industry (Y) }\end{array}$ & $\mathbf{X Y}$ & $\mathbf{X}^{\mathbf{2}}$ & \\
\hline 2005 & 48.7 & 1,026 & $49,966.2$ & $2,371.69$ & $\mathbf{Y}^{\mathbf{2}}$ \\
\hline 2006 & 50.6 & 1,253 & $63,401.8$ & $2,560.36$ & $1,052,676$ \\
\hline 2007 & 54.3 & 1,124 & $61,033.2$ & $2,948.49$ & $1,263,009$ \\
\hline 2008 & 66.1 & 1,974 & $130,481.4$ & $4,369.21$ & $3,896,676$ \\
\hline 2009 & 114.6 & 3,852 & $441,439.2$ & $13,133.16$ & $14,837,904$ \\
\hline 2010 & 195.7 & 5,960 & $1,166,372.0$ & $38,298.49$ & $35,521,600$ \\
\hline & $\sum \mathrm{X}=530.0$ & $\sum \mathrm{Y}=15,189$ & $\begin{array}{l}\sum \mathrm{XY} \\
=3,086,693.8\end{array}$ & $\sum \mathrm{X}^{2}=63,681.4$ & $\sum \mathrm{Y}^{2}=58,142,241$ \\
\hline
\end{tabular}

Source: Extracted from CBN Annual Report and Statement of Account, 2005-2010 
Using $\mathbf{r}=\frac{\sum x y-\sum x \sum y}{\sqrt{\left[n \sum x^{2}-\left(\sum x^{2}\right)\right]\left[n \sum y^{2}-\left(\sum y^{2}\right)\right]}}$

$6(3086693.8)-(530.0 \times 15,189)$

$\sqrt{\left[6(63681.4)-(530.0)^{2}\right]\left[6(58142241)-(15189)^{2}\right]}$

$\frac{10469992.8}{3457626.246}=3.028$

$\therefore r=3.028$

Table 2 above shows the extent of correlation between e-banking practices in Nigeria and increased insecurity of Nigerian banking transactions (measured with number of cases of fraud and forgery in banking industry) since e-banking became prominent in Nigeria. The correlation coefficient of 3.028 was established in the table, implying that there is a very strong positive relationship between the two variables.

\section{Test of Hypothesis 2}

The practice of e-banking in Nigeria is not significantly related to increased total credit facilities granted by Nigerian banks. 
Table 3: The degree of relationship between e-banking practices in Nigeria and the total credit facilities granted by Nigerian banks

\begin{tabular}{|l|l|l|l|l|l|}
\hline Period & $\begin{array}{l}\text { Volume of e- } \\
\text { banking } \\
\text { products } \\
\text { utilized in } \\
\text { Nigeria } \\
\text { (million) } \\
\text { (X) }\end{array}$ & $\begin{array}{l}\text { Total credit } \\
\text { facilities granted } \\
\text { by Nigerian } \\
\text { commercial banks } \\
\text { (N'million) (Y) }\end{array}$ & $\mathbf{X Y}$ & $\mathbf{X}^{2}$ & $\mathbf{Y}^{2}$ \\
\hline 2005 & 48.7 & $1,899,346.4$ & $92,498,169.68$ & $2,371.69$ & 3607516747000 \\
\hline 2006 & 50.6 & $2,524,297.9$ & $127,729,473.7$ & $2,560.36$ & 6372079888000 \\
\hline 2007 & 54.3 & $4,813,488.8$ & $261,372,441.8$ & $2,948.49$ & 23169674430000 \\
\hline 2008 & 66.1 & $7,806,751.4$ & $516,026,267.5$ & $4,369.21$ & 60945367420000 \\
\hline 2009 & 114.6 & $9,667,876.7$ & $1,107,938,670$ & $13,133.16$ & 93467839890000 \\
\hline 2010 & 195.7 & $9,921,678.3$ & $1,941,672,442$ & $38,298.49$ & 98439700290000 \\
\hline & $\sum \mathrm{X}=530.0$ & $\sum \mathrm{Y}=36633439.5$ & $\sum \mathrm{XY}=4,047,237,466$ & $\sum \mathrm{X}^{2}=63,681.4$ & $\sum \mathrm{Y}^{2}=286002178700000$ \\
\hline
\end{tabular}

Source: Extracted from CBN Annual Report and Statement of Account, 2007, 2009 and 2010.

$$
\text { Using } \mathbf{r}=\frac{\sum x y-\sum x \sum y}{\sqrt{\left[n \sum x^{2}-\left(\sum x^{2}\right)\right]\left[n \sum y^{2}-\left(\Sigma y^{2}\right)\right]}}
$$




$$
6(40472374466)-(530.0 \times 36633439.5)
$$

$\sqrt{\sqrt{\left.6(63681.4)-(530)^{2}\right]\left[6(286002178700000)-(36633439.5)^{2}\right]}}$

\section{$\frac{2234185238}{615181963.4}=3.632$}

Table 3 shows the degree of relationship that exist between e-banking practices in Nigeria and total credit facilities granted by Nigerian banks. The correlation coefficient of 3.632 which the table established shows a very strong positive relationship existing between the practice of ebanking in Nigeria and the increase in the total credit facilities granted by Nigerian banks.

\section{Test of Hypothesis 3}

Significant relationship does not exist between the level of deposits (savings and time deposits) with Nigerian banks and e-banking practices in Nigeria. 
Table 4: The extent at which e-banking system has improved the level of deposits (Savings and time deposits) with Nigerian banks

\begin{tabular}{|l|l|l|l|l|l|}
\hline Period & $\begin{array}{l}\text { Volume of e- } \\
\text { banking products } \\
\text { utilized in Nigeria } \\
\text { (million) } \\
(\mathbf{X})\end{array}$ & $\begin{array}{l}\text { Savings and time } \\
\text { deposit with } \\
\text { Nigerian } \\
\text { Commercial Banks } \\
\text { (N'million) (Y) }\end{array}$ & $\mathbf{X Y}$ & $\mathbf{X}^{2}$ & $\mathbf{Y}^{2}$ \\
\hline 2005 & 48.7 & $1,316,957.4$ & 64135825.38 & 2371.69 & 1734376793000 \\
\hline 2006 & 50.6 & $1,739,636.9$ & 88025627.14 & 2560.36 & 3026336544000 \\
\hline 2007 & 54.3 & $2,693,554.3$ & 146259998.5 & 2948.49 & 7255234767000 \\
\hline 2008 & 66.1 & $4,118,172.8$ & 272211222.1 & 4369.21 & 16959347210000 \\
\hline 2009 & 114.6 & $5,763,511.2$ & 660498383.5 & 13133.16 & 33218061350000 \\
\hline 2010 & 195.7 & $5,924,182.3$ & 1159362476 & 38298.49 & 35095935920000 \\
\hline & $\sum \mathrm{X}=530.0$ & $\sum \mathrm{Y}=21556014.9$ & $\sum \mathrm{XY}=2258859534$ & $\sum \mathrm{X}^{2}=63681.4$ & $\sum \mathrm{Y}^{2}=97289292580000$ \\
\hline
\end{tabular}

Source: Extracted from CBN Annual Report and Statement of Account, 2007, 2009 and 2010.

$$
\text { Using } \mathbf{r}=\frac{\sum x y-\sum x \sum y}{\sqrt{\left[n \sum x^{2}-\left(\sum x^{2}\right)\right]\left[n \sum y^{2}-\left(\sum y^{2}\right)\right]}}
$$


$6(2258859534)-(530.0 \times 21556014.9)$

$\sqrt{\left[6(63681.4)-(530)^{2}\right]\left[6(97289292580000)-(215560149)^{2}\right]}$

\section{$\frac{2128469300}{3471153300}=0.613$}

Table 4: shows the computation of Pearson's correlation coefficient on the extent at which e-banking system has improved the level of deposits with Nigerian banks. 0.613 which is close to +1 was shown in the table as the correlation coefficient. This indicates that there is a strong relationship between the practice of e-banking in Nigeria and improve in the level of deposits with Nigerian banks.

\section{Summary of Findings}

Based on the analysis carried out, the following findings were discovered:

1. It was revealed that there is a significant relationship between ebanking practices in Nigeria and the rate of increase in the insecurity of banking transactions (measured with fraud and forgery in banking industry between 2005 and 2010). This shows that most of the successful fraud cases were perpetuated via electronic means reflecting insecurity of banking transaction via electronic means.

2. The study also revealed that the practice of e-banking in Nigeria is significantly related to increased total credit facilities granted by Nigerian banks. This was established in table 2 where the null hypothesis two was rejected as a result of $2.760 \mathrm{t}-$ calculated which exceeds 2.182 t-table value when the significance of the relationship was tested using t-test statistics. Hence, e-banking has improved the total credit facilities granted by Nigerian banks. This result is in line with the findings of Agboola (2001) who studied the impact of computer automation on the banking services in Lagos and discovered 
3. that electronic banking has tremendously improved the services of some banks to their customers in Lagos.

4. Furthermore, it was discovered that a significant relationship does exists between the level of deposit with Nigerian banks and the practice of e-banking in Nigeria. This was justified in table 3 where the test for significance of relationship between the two variables were computed. The t-calculated of 3.168 that exceeds the t-table value of 2.182 left the null hypothesis (null hypothesis three) that says that "'significant relationship does not exist between the level of deposits (savings and time deposits) with Nigerian banks and e-banking practices in Nigeria", rejected. Therefore, e-banking system has actually improved the level of Nigerian banks' deposits.

\section{Conclusion/Recommendation}

Although, the security problem may have seen to be a crucial issue in the practice of e-banking in Nigeria but that could not imply that the operational efficiency of e-banking is impaired. This is because the core banking operations of accepting deposits, granting credit facilities and facilitating cash withdrawal have empirically proved to have improved with the introduction of e-banking in Nigeria (see table 1, table 2 and table 3 respectively). In the support of this paper, Woherem (2000) opined that only banks that overhaul the whole of their payment and delivery system and apply ICT to their operations are likely to survive and prosper in the new millennium. Therefore it can be concluded that e-banking introduction in Nigeria had aid to enhance Nigerian banking operations vis-à-vis banks employees' productivity cum general performance. Consequent upon this, the researcher recommended the following:

1. Government through $\mathrm{CBN}$ should provide adequate security measures towards the various e-banking products in Nigeria. This will aid in reducing the rate of fraud and forgery in the banking industry and encourage investors which in turn will increase the banks' cash inflow cum use of available fund for granting of credit facilities.

2. Banks should regularly train their workers who in turn will educate their customers on electronic banking system and its products. This 
3. will enhance the indepth understanding of the products and the way they are being used. Hence more customers cum deposits will be attracted. Besides this, the apex bank should also organize seminars, workshops, symposia and public lectures to bank customers and general public on the application of information and technology cum e-banking system. This will aid to increase the use of various e-banking products in Nigeria especially in this era of cashless economy drive.

4. Banks should in addition to the storage of information in the computer, maintain the manual filing of all the relevant documentary evidence of information in their financial statement so as to avoid loss of audit trail, with an understanding that ebanking in Nigeria is an "add process" and not an "or process".

\section{References}

Agboola, A.A. (2001) 'Impact of Electronic Banking on Customer services in Lagos, Nigeria', In Ife Journal of Economics and Finance. Vol., 5, Nos. $1 \& 2$.

Agboola, A.A. (2006) 'Electronic Payment System and Tele-banking Services in Nigeria', In Journal of Internet Banking and Commerce, Vol. 11, No. 3, Available from http://www.arraydev.com/commerce/jibc (Accessed 20 August 2011).

Agnes, C.E. (2000) 'Electronic Baking in Nigeria: Concept, Policy Issues and Supervisory Framework' In Bullion publication of the Central Bank of Nigeria. Volume 24.No. 4

Anyaoha, C. J. (2010) The effect of Electronic Banking on Accounting information system in Nigerian Banks, Unpublished B.Sc thesis.

Bank of International Settlement (1996) Implications for Central bank on the development of Electronic Money, BIS Balse

Carys, C. (1995) Business Technology, $2^{\text {nd }}$ ed, New York, Heinemann. 
Central Bank of Nigeria (2010) Annual Report and Statement of Accounts, Available from www.cenbank.org (Accessed 12 February 2012).

Central Bank of Nigeria (2003) Guidelines on Electronic Banking in Nigeria, Available from http://www.cenbank.org/OUT/PUBLICATIONS/BSD/2003/EBANKING . PDF. (Accessed 24 August 2011).

Dogarawa, A. B. (2005) The impact of E-banking on customer satisfaction. Zaria, Department of Accounting, Ahmadu Bello University.

Ezeoha, A.E. (2005) Regulatory Internet Banking in Nigeria: Problems and Challenges-Part 1, Available from http:/www.arraydev.com/commerce/jibc (Accessed $18 \mathrm{March}$ 2010).

Haundin, A. (2007) 'Internet Banking Adoption among Young Intellectuals' Vol. 1 12, No. 3, Available from http://www.arraydev.com/commerce/jibc/ (Accessed 20 May 2011).

Iloboya, O. J. (2005) 'An Empirical Assessment of the operational Efficiency of Electronic Banking in Nigeria' In Bayero International Journal of Accounting Research. Vol. 1, No. 2

Irechukwu, G. (2000) 'Enhancing the Performance of Banking Operations Through Appropriate Information Technology' In Information Technology in Nigeria Banking Industry, Ibadan, Spectrum Books.

Iyabi, D. P. (1997) Smart card in Nigerian Banking - All states Trust Bank Practical Experience. Lagos, FITC most shop for Top Exercise. 
Laudon, D.P. and Laudon, J.P. (1991) Business Information System: A Problem Solving Approach, New York, HBJ, College Publishers.

Ondunfa, A. (2000) 'The future of Banking in Nigeria', In Information Systems Group, Lagos, Philip Consulting Limited.

Onwumere, J.U.J. (2009) Business and Economic Research Methods, Enugu, Vougasen Limited.

Osabuohien, E.S.C (2005) 'ICT and Nigerian Banks Reforms: Analysis of Anticipated Impact in Selected Banks', In Global Journal of Business Research, Vol. 2, No. 2.

Osuala, E.C. (1982) Introduction to Research Methodology, Onitsha, Africana FEP, Publishers.

Oyesanya, F. (2007) Review of Central Bank Guideline for Electronic Banking, Available from http://www.centbank.org/out/publication/bsd/2003/e-banking PDF (Accessed 15 August 2010).

Salawu, R. O. and Salawu, M. K. (2007) The emergency of internet banking in Nigeria: An appraisal, Available from http://scialet.net/fulltext/?doi=itj.2007.490.496 (Accessed 11 August 2010). 


\section{APPENDIX A}

I. The Volume of different E-Banking Products used in Nigeria in 2010

\begin{tabular}{|l|l|}
\hline $\begin{array}{l}\text { E-banking products (e-payment } \\
\text { segments) }\end{array}$ & Volume (Millions) in 2010 \\
\hline ATM & 186.2 \\
\hline Web (Internet) banking & 7.2 \\
\hline POS terminals & 1.1 \\
\hline Mobile banking & 1.2 \\
\hline Total & 195.7 \\
\hline
\end{tabular}

Source: Extracted from CBN Annual Report and Statement of Account, 2010

II. The Volume of total e-banking products utilized in Nigeria for Years

2005-2010

\begin{tabular}{|l|l|}
\hline Period & $\begin{array}{l}\text { Volume of e-banking products } \\
\text { utilized (millions) }\end{array}$ \\
\hline 2005 & 48.7 \\
\hline 2006 & 50.6 \\
\hline 2007 & 54.3 \\
\hline 2008 & 66.1 \\
\hline 2010 & 114.6 \\
\hline
\end{tabular}

Source: Extracted from CBN Annual Report and Statement of Account, 2007, 2009 and 2010 
III. Savings and time deposit with Nigerian Commercial Banks for the

Years 2005 - 2010

\begin{tabular}{|l|l|}
\hline Period & $\begin{array}{l}\text { Savings and time deposit with Nigerian } \\
\text { Commercial Banks } \\
\text { (A' million) }\end{array}$ \\
\hline 2005 & $1,316,957.4$ \\
\hline 2006 & $1,739,636.9$ \\
\hline 2007 & $2,693,554.3$ \\
\hline 2008 & $4,118,172.8$ \\
\hline 2009 & $5,763,511.2$ \\
\hline 2010 & $5,924,182.3$ \\
\hline
\end{tabular}

Source: Extracted from Savings Statistics (Cumulative) in CBN Annual Report

2009 and 2010

IV. Total Credit Facilities Granted by Nigerian Commercial Banks

Between 2005 and 2010

\begin{tabular}{|l|l|}
\hline Period & $\begin{array}{l}\text { Total Credit facilities Granted by Nigerian } \\
\text { Commercial Banks (N' million) }\end{array}$ \\
\hline 2005 & $1,899,346.4$ \\
\hline 2006 & $2,524,297.9$ \\
\hline 2007 & $4,813,488.8$ \\
\hline 2008 & $7,806,751.4$ \\
\hline 2009 & $9,667,876.7$ \\
\hline
\end{tabular}

Source: Extracted from Deposit Money Banks' Returns in CBN Annual Report 2009 and 2010. 
V. Fraud and Forgery in banking industry between years 2005 $-2010$

\begin{tabular}{|c|l|}
\hline Period & $\begin{array}{l}\text { Number of reported cases of } \\
\text { attempted or successful fraud and } \\
\text { forgery }\end{array}$ \\
\hline 2005 & 1,026 \\
\hline 2006 & 1,253 \\
\hline 2007 & 1,124 \\
\hline 2008 & 1,974 \\
\hline 2009 & 3,852 \\
\hline 2010 & 5,960 \\
\hline
\end{tabular}

Source: Extracted from CBN Annual Report and Statement of Account, 2006, 2008 and 2010 